\title{
ГЕНОТИПИЧЕСКИЙ ФОН STAPHYLOCOCCUS AUREUS ПРИ СИМБИОТИЧЕСКОМ ВЗАИМОДЕЙСТВИИ С ПРОТИСТАMИ BLASTOCYSTIS SPP
}

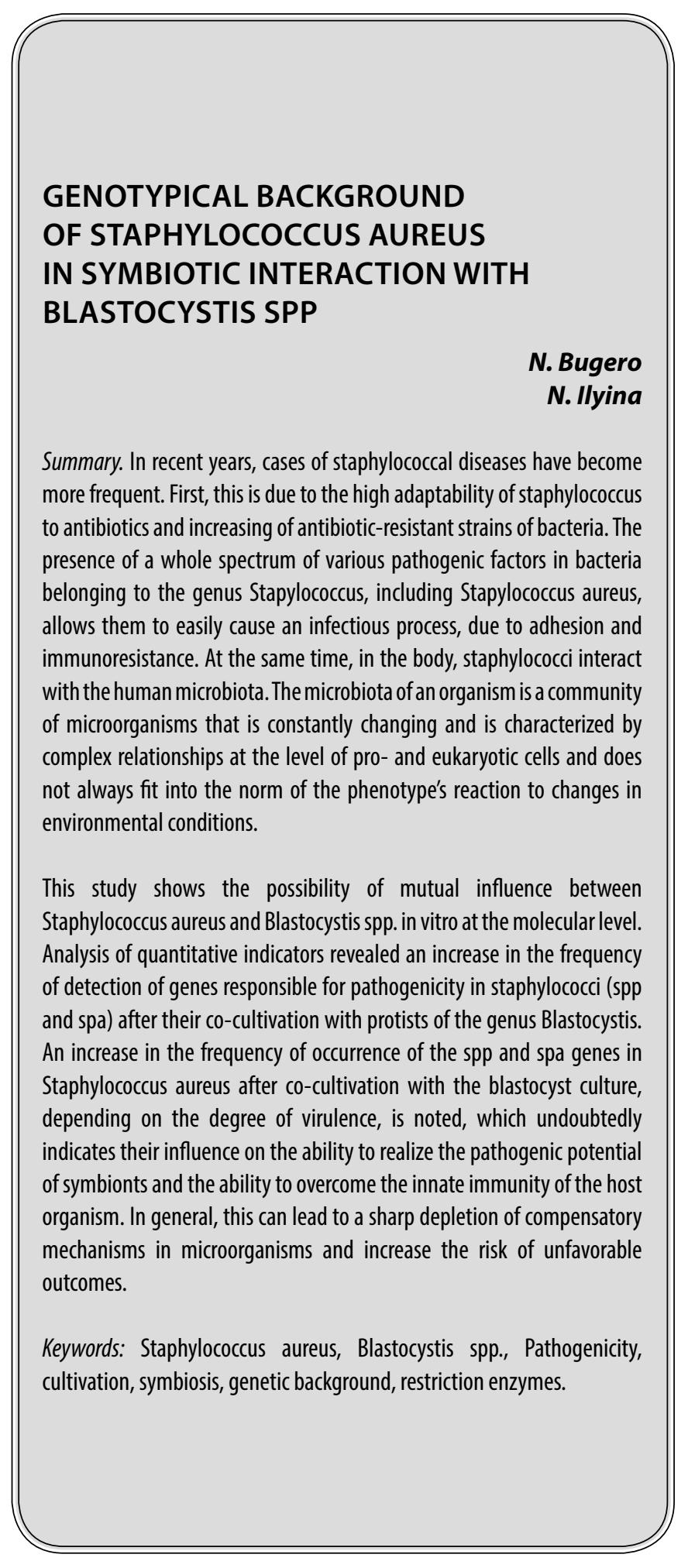

Бугеро Нина Владимировна

Д.б.н., профессор, ФГБОУВО «Псковский государственный университет»

bugero@mail.ru

Ильина Наталья Анатольевна

Д.б.н., профессор, ФГБОУВО «Псковский государственный университет» ilina@mail.ru

Аннотация. В последние годы участились случаи стафилококковых заболеваний. Прежде всего это объясняется высокой приспособляемостью стафилококка к антибиотикам, увеличением антибиотикоустойчивых штаммов бактерий. Присутствие целого спектра различных факторов патогенности у бактерий, относящихся к роду Stapylococcus, в том числе и Stapylococcus aureus, позволяет им легко вызывать инфекционный процесс, за счет адгезии и иммунорезистентности. Вместе с тем в организме стафилококки взаимодействуют с микробиотой человека. Микробиота организма представляет собой сообщество микроорганизмов, которое постоянно меняется и характеризуется сложными взаимоотношениями на уровне клеток прои эукариот. Иногда эти изменения могут не соответствовать норме реакции признаков организма, необходимой для данных условий среды.

В данном исследовании показана возможность взаимовлияния между Staphylococcus aureus и Blastocystis spp. в условиях in vitro на молекулярном уровне. Анализ количественных показателей обнаружил рост в показателях встречаемости генетических детерминант, кодирующих факторы патогенности стафилококков (spp и spa) при совместном выращивании их с протистами рода Blastocystis. Отмечено, что этот рост детекции этих генов имеет прямую зависимость со степенью вирулентности простейших. Это может говорить об взаимовлиянии симбионтов в процессе реализации патогенных факторов и возможностей для преодоления врожденного иммунитета организма-хозяина. В целом это может привести к резкому истощению компенсаторных механизмов у макроорганизмов и повысить риск неблагоприятных исходов.

Ключевые слова: Staphylococcus aureus, Blastocystis spp., патогенность, культивирование, симбиоз, генетический фон, рестриктазы. 


\section{Ввемение}

B настоящее время становится очевидно, что взаимоотношения между микроорганизмами необходимо учитывать в патогенезе многих заболеваний. Поэтому их исследования приобретают широкий характер, оказывая влияние на развитие большинства областей медицины и биологии. Изучение генетического фона в вопросах симбиотического взаимодействия микроорганизмов способствует выявлению основных взаимоадаптационых механизмов клеток бактерий как друг с другом, так и с группой эукариот в постоянно меняющихся условиях сложившегося биотопа [1].

В последние десятилетия наблюдается увеличение роли условно-патогенных микроорганизмов (УПМ) в инфекционной заболеваемости населения [2]. Это относится к бактериям рода Staphylococcus - грамположительным факультативно-анаэробным малоподвижным бактериям, наиболее патогенными представителями, которых считаются Staphylococcus aureus.

За последние годы стафилококковые заболевания встречаются чаще, заболеваемость имеет тенденцию к дальнейшему увеличению. Такой рост стафилококковых инфекций объясняется высокой приспособляемостью этого микроба к антибиотикам, увеличением антибиотикоустойчивых штаммов стафилококков [3]. S. aureus является обычным обитателем различных экотопов здорового человека и входит в состав микробных сообществ. Состав микробных сообществ является очень важным, поскольку являясь оппортунистическим патогеном золотистый стафилококк может начать размножаться при нарушении баланса микрофлоры [4].

Стафилококовая инфекция проявляется в виде острого гастроэнтерита. Инфекционный процесс затрагивает клетки крови: эритроциты и лейкоциты, вызывая их гибель. Также начинаются процессы некроза тканей. Этим процессам способствуют факторы патогенности стафилококков: экзотоксин, энтеротоксин и фермент коагулаза [5].

Усиление отрицательного действия условно-патогенных бактерий вызывает большое беспокойство в биологических и медицинских сферах. Известно, что вид St. aureus в своём генотипе имеет все 4 фактора патогенности. Однако, недостаточно изученными остаются молекулярно-генетические механизмы участвующие в формировании новых вариантов фено- и генотипов стафилококков [6, 7].

Сейчас становится очевидным, что крайне важно изучать микроогранизмы в микробных сообществах, а не только в чистых культурах. В современной литера- туре, для изучение этого вопроса употребляется понятие «симбиоз», что подразумевает длительный контакт между симбионтами в пределах изучаемого биотопа и формирование специализированных симбиотических связей между микроорганизмами, направленных на приобретение тех или иных биологических свойств [8].

Простейшие Blastocystis spp. паразитируют в толстой кишке, вызывая бластоцитоз. Это заболевание известно относительно немного времени. Тем не менее известен факт того, что возбудитель бластоцистной инвазии может активно размножаться при снижении иммунитета у организма-хозяина или при взаимодействии с другими микроорганизмами $[9,10]$.

Данные, полученные исследователями, как правило, ограничиваются изучением их симбиотического взаимодействия, основанным только на исследованиях вне организма-хозяина, и не касаются изучения сложившихся симбиотических групп микроорганизмов внутри изучаемого биотопа, что, конечно же, представляет собой научный интерес. Выяснение закономерностей образования, функционирования симбиотических ассоциаций микроорганизмов в экотопах организма человека и модельных системах in vitro представляет собой интерес для более точного определения участия условно-патогенной микробиоты при заболеваниях организма хозяина.

Целью настоящей работы является исследование генетического фона встречаемости генов патогенности Staphylococcus aureus при симбиотическом взаимодействии с Blastocystis spp. in vitro.

\section{Материалы и метоны исследования}

При проведении исследования у больных и лиц контрольной группы отбиралась проба фекалий для выделения штаммов Staphylococcus aureus и Blastocystis spp. Микрофлора кишечника больных и лиц контрольной группы определялась согласно приказу Минздрава России от 09.06.2003 г. № 231 «Об утверждении отраслевого стандарта «Протокол ведения больных. Дисбактериоз кишечника» (ОСТ 91500.11.0004-2003).

В результате работы была создана коллекция из 199 изолятов Staphylococcus aureus от больных добровольцев. Параллельно в пробах фекалий осуществлялся поиск простейших рода Blastocystis. Бластоцисты были выявлены только у 132 добровольцев. Наличие бластоцист выявляли при микроскопировании препаратов окрашенных раствором Люголя, полученных из фекалий лиц, принимающих участие в эксперименте. Чистую культуру простейших рода Blastocystis получали путем заливания отобранных проб фекалий равным объемом 
Таблица 1. Характеристика праймеров для генов ssp и spa y Staphylococcus aureus

\begin{tabular}{|l|l|l|}
\hline Гены & Нуклеотидная последовательность $\left(\mathbf{5}^{\prime} \longrightarrow \mathbf{3}^{\prime}\right)$ & Размер амплификата, п.н. \\
\hline ssp & $\begin{array}{l}\text { AGCACCAAAAGAGGAAGACAA } \\
\text { GTTTAACGACATGTACTCCGT }\end{array}$ & $250-450$ \\
\hline spa & $\begin{array}{l}\text { ATCMATTTYGCMAAYGATGACCA } \\
\text { TTGTCTGAATTATTGTATCGCC }\end{array}$ & $200-250$ \\
\hline
\end{tabular}

(1:1) физиологического раствора, суспензированием и дальнейшим фильтрованием. Полученной жидкостью в объеме 0,5-1,0 мл инокулировали пробирку с питательной средой Павловой (хлорид натрия - 8,5 г, двузамещенный фосфорно-кислый натрий - 0,59 г, однозамещенный фосфорно-кислый калий $-0,45$ г, вода - 1000 мл. Стерильная бычья сыворотка в соотношении 1:20). Культивирование простейших рода Blastocystis проводили на этой же среде.

Выделение чистых культур стафилококков проводили методом высева патматериала (фекалии) на чашку Петри с мясопептонным молочно-солевым агаром с 7,5\% раствором поваренной соли и $10 \%$ молочной сыворотки. (Матвеев К.И. Руководство по микробиологической диагностике инфекционных болезней)

Для идентификации выделенных культур S. aureus до вида применяли морфолого-культуральные и физиолого-биохимические методамы, в том числе с помощью тест-систем «STAPHYtest» («Erba Lachema s.r.o.», European Union).

Выделение общей ДНК из бактериальных изолятов S. aureus проводили с использованием набора реактивов «ДНК-сорб-В» («ИнтерЛабСервис», Россия). Для выделения ДНК брались суточные культуры стафилококков с агаризованной питательной среды.

Для исследования молекулярных детерминант патогенности S. aureus (гены ssp и spa) использовали метод ПЦР. Праймеры к данным генам подбирали с использованием программы PrimerSelect (DNASTAR, Inc США). Hyклеотидные последовательности праймеровпредставлены в таблице 1.

Амплификацию осцществляли на ПЦР-амплификаторе «Терцик» (НПФ «ДНК-технология», Москва) с «hot start». «Hot start» обеспечивался разделением реакционной смеси в эппендорфе воском на два слоя (верхний и нижний). Реакцию проводили в эппендорфах в объеме 25 мкл. Амплификацию проводили при следующих параметрах: 1 цикл: $95^{\circ} \mathrm{C}, 5$ мин; 2 цикл: $95^{\circ} \mathrm{C}, 30$ сек; $60^{\circ} \mathrm{C}$, 30 сек; $75^{\circ} \mathrm{C}$, 30 сек; 20 повторов; последний цикл: $75^{\circ} \mathrm{C}$, 2 мин. Результаты амплификации визуализировали с использованием стандартных наборов фирмы «ИнтерЛабСервис» в 1,7\% агарозном геле, содержащим бромистый этидий, с применением буфера ТАЕ. Маркером длин ДНК служила 50+ bp DNA Ladder (ЕвроГен, Россия). При обнаружении в геле светящейся полосы определенной массы делали вывод о наличии исковых генов.

Вирулентность излятов простейших рода Blastocystis определяли при помощи метода рестрикционного анализа. Этот метод основан на анализе полиморфизма длин фрагментов, полученных при рестрикции (ПДФР) ДНК. В исследовании применялись две эндонуклеазы рестрикции (рестриктазы): Hind III и Pst I (НПО «СибЭнзим», Россия), с использованием соответствующего буфера. Длины полученных в ходе процесса рестриукции фрагментов определяли при помощи маркеров молекулярной длины ДНК 100bp + 1,5 Кb ДНК маркер (НПО «СибЭнзим», Россия). Определение размера полученных фрагментов осуществляли с использованием программы Gel Pro Analyzer, версия 4.0.00.001 (Media Cybernetics, Inc., США). Идентичность длин фрагментов была рассчитана для каждой пары микроорганизмов, методом сравнения рестрикции отдельно по каждой рестриктазе для микроорганизма. При сравнении длин фрагментов одинаковыми считали фрагменты ДНК, длина которых различалась в пределах 5\%.

Высоко вирулентные и слабо вирулентные бластоцисты были обнаружены в результате применения рестриктазы Hind III на основе наличия фрагментов ДНК размером 380, 600 п.н. и 700 п.н., соответственно, бластоцисты со слабовыраженными свойствами были обнаружены с применением рестриктазы Pst I на основе наличия фрагментов ДНК размером около 1000 п.н.

Статистическую обработку полученных данных проводили при помощи программы «Statistica for Windows» [1].

\section{Результаты исслеАования и их обсу жАения}

Всего было отобрано 132 штамма S. aureus выделенных у лиц с заболеваниями пищеварительного тракта. Данные о заболеваниях испытуемых и выделенных от них штаммов представлены в таблице 2. В результате проведенной работы были обнаружены различия в частоте встречаемости исследуемых генов (ssp и spa) у штаммов золотистого стафилококка. 
Таблица 2. Количественные показатели генов у штаммов Staphylococcus aureus, выделенных у лиц с заболеваниями органов пищеварения

\begin{tabular}{|c|c|c|c|}
\hline \multirow[t]{2}{*}{$\begin{array}{l}\text { Особенности выделения } \\
\text { S. aureus }\end{array}$} & \multirow[t]{2}{*}{$\begin{array}{l}\text { Число штаммов } \\
\text { (n) }\end{array}$} & \multicolumn{2}{|c|}{$\begin{array}{l}\text { Генная характеристика } \\
\text { S. aureus } \\
\text { (aбc./\%) }\end{array}$} \\
\hline & & ssp & spa \\
\hline Язв. болезнь желудка & 63 & $43 / 67,2$ & $39 / 61$ \\
\hline $\begin{array}{l}\text { Язв. болезнь 12-перстной } \\
\text { кишки }\end{array}$ & 28 & $21 / 75,0$ & $18 / 64,3$ \\
\hline Язв. колит & 13 & $5 / 38,5$ & $1 / 7,7$ \\
\hline Холецистит & 17 & $6 / 35,3$ & $4 / 23,5$ \\
\hline Панкреатит & 11 & $3 / 27,3$ & - \\
\hline
\end{tabular}

Таблица 3. Изменение частоты гена spр у культур S. aureus в зависимости от присутствия в среде Blastocystis spp.

\begin{tabular}{|c|c|c|}
\hline S. aureus в симбиозе с Blastocystis spp. & $\begin{array}{l}\text { До / после совместного } \\
\text { культивирования }\end{array}$ & Частота встречаемости гена spp (\%) \\
\hline \multirow{2}{*}{$\begin{array}{l}\text { Слабовирулентные штаммы бластоцист } \\
(n=24)\end{array}$} & до & $5,82 \pm 0,7$ \\
\hline & на 7-е сутки после & $9,67 \pm 1,5$ \\
\hline \multirow{2}{*}{$\begin{array}{l}\text { Умеренновирулентные штаммы бластоцист } \\
(n=71)\end{array}$} & до & $25,25 \pm 1,8$ \\
\hline & на 7-е сутки после & $36,40 \pm 1,8^{*}$ \\
\hline \multirow{2}{*}{ Высоковирулентные бластоцист ( $n=37)$} & до & $82,56 \pm 5,8$ \\
\hline & на 7-е сутки после & $90,61 \pm 8,3^{*}$ \\
\hline \multirow{2}{*}{$\begin{array}{l}\text { S.aureus } \\
\text { (монокультуры) }(n=67)\end{array}$} & до & $4,26 \pm 0,7$ \\
\hline & на 7-е сутки после & $7,24 \pm 1,6$ \\
\hline
\end{tabular}

* — показатель достоверности различия между частотой встречаемости фрагмента гена sрр у культур S. aureus $(\mathrm{p}<0,05)$.

Анализ данных таблицы продемонстрировал, что золотистый стафилококк чаще обладал геном ssp. Данный ген с большей частотой регистрировался у штаммов S.aureus, выделенных от больных с язвенной болезнью 12 -перстной кишки и желудка $(75,0 \%$ и $67,2 \%$, соответственно). Так, из 28 штаммов стафилококков, выделенных из фекалий лиц с заболеваниями язвенной болезни 12-перстной кишки у более половины штаммов (64,3\%) обнаруживался ген spa. Наименьшее процентное содержание гена spa, было зарегистрировано у лиц, с заболеванием - язвенный колит (7,7\%) штаммов S.aureus. Согласно полученным результатам, ген spa не регистрировался у штаммов культуры стафилококкков, которые были выделены у лиц, с заболеванием панкреатит.

В дальнейшие планы работы входил анализ изолятов S.aureus обладающих симбиозом со слабовирулентными, умеренно- и высоковирулентными простейшими рода Blastocystis ( $n=132$, группа 1 ) и без него $(n=67$, группа 2). Простейшие различались по степени вирулентности.
Стафилококки могут связывать Fс защитных иммуноглобулинов и создавать защиту бактерий от гуморальных факторов иммунитета организма-хозяина. Известно, что за этот процесс отвечает протеин А и его ген spр можно использовать для анализа патогенности стафилококков. В таблице 1 дано описание нуклеотидных последовательностей праймеров к участку гена spp и spa S.aureus. Мы приняли, что наличие одной единицы идентифицированного гена можно считать равным одной бактерии, поэтому количество определяемых искомых фрагментов ДНК гена spp $S$.aureus соответствовало количеству бактерий.

Результаты проведенного анализа показали (таблица 3), что у изолятов S.aureus различалось число генов патогенности $s p p$, выделенных из симбиотического сообщества в зависимости от степени вирулентности бластоцист.

Ген spp в монокультуре стафилококков выявлялся у $5,82 \pm 0,7 ; 25,25 \pm 1,8$ и $82,56 \pm 5,8 \%$ штаммов соответствен- 
но, в то время как после культивирования со штаммами бластоцист разной степени вирулентности данные показатели достоверно возросли до 9,67 + 1,5\% для слабовиру-

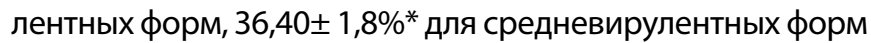

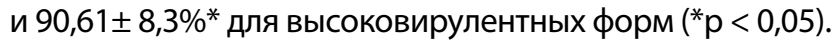

Таким образом, данный опыт показал, что при выращивании штаммов S. aureus с бластоцистами растет доля патогенных штаммов стафилококков, обладающих с геном spp. При этом существовала зависимость от вирулентности штамма рода Blastocystis. Чем выше была вирулентность простейшего, тем чаще встречались гены spp.

Анализируя результаты исследования в отношении гена spa у штаммов золотистого стафилококка до и после сокультивирования с протистами Blastocystis spp., показано, что частота встречаемости генетической детерминанты патогенности spa была зарегистрирована значительно реже, чем гена spр. Так, до сокультивиро-

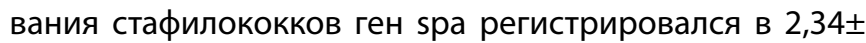
0,2\% случаев, на 7-е сутки после сокультивирования

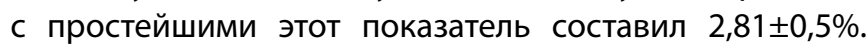
Необходимо отметить, что сокультивирование штаммов стафилококков с бластоцистами различной степени вирулентности показало неоднозначный результат, выражающийся в увеличении частоты встречаемости фрагмента искомого гена (spa) как в группе со слабовирулентыми штамамми бластоцист, так и в группе высоковирулентных простейших. Эти показатели составили до сокультивирования стафилококков со слабовирулен-

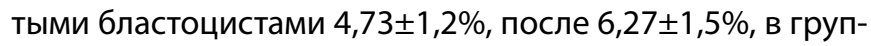
пе с высоковирулентными штаммами бластоцист до совместного культивирования ген sра был обнаружен

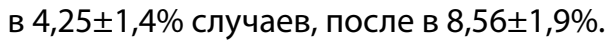

Однако у стафилококков с бластоцистами, обладающих умеренновирулентными характеристиками патогенности частота встречаемости искомого гена до и после сокультивирования с простейшими значительно не изменялась и составила до культивирования $3,04 \pm 0,6 \%$, после $3,2 \pm 0,8 \%$, что по всей вероятности объясняется возможностью нахождением некого ком- промисса между штаммами золотистого стафилококка и бластоцистами, обладающих умеренновирулентными свойствами во время их совместного культивирования и дальнейшего сожительства.

\section{Зак^ючение}

На основании данных, полученных в данном исследовании показано значительное генетическое разнообразие исследуемых штаммов Staphylococcus aureus, выделенных у больных желудочно-кишечного тракта во всех группах исследуемых лиц, что свидетельствует о выраженном патогенном потенциале бактерий. Сравнение генетического разнообразия изолятов золотистого стафилококка показало широкое распространение генетических детерминант, определяющих патогенность этих бактерий, изолированных от лиц, имеющих заболевания язвенной болезни желудка и 12-перстной кишки. Наиболее часто гены spp и spa были выделены у лиц с язвенной болезнью 12-перстной кишки $(75,0 \%$ и 64,3\%) соответственно.

Выращивание стафилококков вместе с бластоцистами оказывает влияние на частоту встречаемости детерминант патогенности (гена spp) стафилококков.

Среди штаммов стафилококков, исследованных в данной работе, наибольшую вирулентность приобрели штаммы при выращивании с более вирулентными штаммами бластоцист. Таким образом была выявлена прямая зависимость между этими двумя факторами. Вероятно, это говорит о способности взаимовлияния на патогенный потенциал у симбионтов.

Таким образом, на искусственных питательных средах в симбиотических взаимоотношениях стафилококков с различными по вирулентности бластоцистами происходит взаимоадаптация штаммов симбионтов. Вероятно, подобный механизм можно рассматривать и в условиях макроорганизма in vivo. Данные гены могут быть рекомендованы к использованию для диагностики возбудителей инфекционных заболеваний желудочно-кишечной этиологии.

\section{ЛИТЕРАТУРА}

1. Козлова Ю.Н., Фоменко Н.В., Морозова В.В. Генетическая и биохимическая характеризация стафилококков, встречающихся в Новосибирске. Вавиловский журнал генетики и селекции. 2017; 21(8):952-958.

2. Бондаренко B.M. Мавзютов A.P., Golkocheva Е. Секретируемые факторы патогенности энтеробактерий // Журн. микробиологии, эпидемиологии и иммунобиологии. - 2002.— № 1.- С. 84-90.

3. Zhang F., Ledue 0., Jun M. et al. Protection against Staphylococcus aureus colonization and infection by B- and T-Cell-mediated mechanisms. MBio. 2018. 9(5). (doi: 10.1128/mBio.01949-18).

4. Гриценко В.А., Карташова 0.Л., Пашкова Т.М., Тяпаева Я.В., Белозерцева Ю.П., Курлаев П.П., Мавзютов А.Р., Владимирова А.А. Гены sdr: распространенность среди изолятов Staphylococcus aureus, выделенных из разных биотопов тела человека. Бюллетень Оренбургского научного центра Ур0 РАН. 2017. № 1. 15 с. [Электр. ресурс] (URL: http://elmag.uran.ru:9673/magazine/Numbers/2017-1/Articles/VAG-2017-1.pdf). (doi:10.24411/2304-9081-2017-00015). 
5. Карташова 0.Л., Киргизова С.Б., Потехина Л.П., Бухарин О.В. Диагностическое значение персистентных характеристик стафилококков при бактерионосительстве. Журнал микробиологии, эпидемиологии и иммунобиологии. 2007. 5: 13-16.

6. Shettigar K., Jain S., Bhat D.V. et al. Virulence determinants in clinical Staphylococcus aureus from monomicrobial and polymicrobial infections of diabetic foot ulcers. J Med Microbiol. 2016. 65(12): 1392-1404. (doi: 10.1099/jmm.0.000370).

7. Карташова 0.Л., Пашкова Т.М., Тяпаева Я.В., Белозерцева Ю.П., Курлаев П.П., Мавзютов А.Р., Гриценко В.А. Staphylococcus aureus: генетическое разнообразие с учетом источника выделения. Бюллетень Оренбургского научного центра Ур0 PAH. 2018. 3. 10с. [Электр.pecypc] (URL: http://elmag.uran.ru:9673/ magazine/ Numbers/2018-3/Articles/KOL-2018-3.pdf). DOI: 10.24411/2304-9081-2018-13014.

8. Бухарин 0.В. Межбактериальные взаимодействия / 0.В. Бухарин, Б.Я. Усвяцов, Л.М. Хуснутдинова // Микробиология. — 2003.— № 4.—C. 3-8.

9. Бугеро Н.В. Современный молекулярно-генетический подход определения вирулентности простейших // Международный журнал экспериментального образования.-2016. - N5.-C. 305-308.

10. Соломай Т.В. Бластоцистоз человека: от механизмов взаимодействия паразита с организмом хозяина к клиническим проявлениям // Санитарный врач. - 2018. - № 8.- C. 35-42.

( Б Бугеро Нина Владимировна ( bugero@mail.ru ), Ильина Наталья Анатольевна ( ilina@mail.ru ).

Журнал «Современная наука: актуальные проблемы теории и практики»

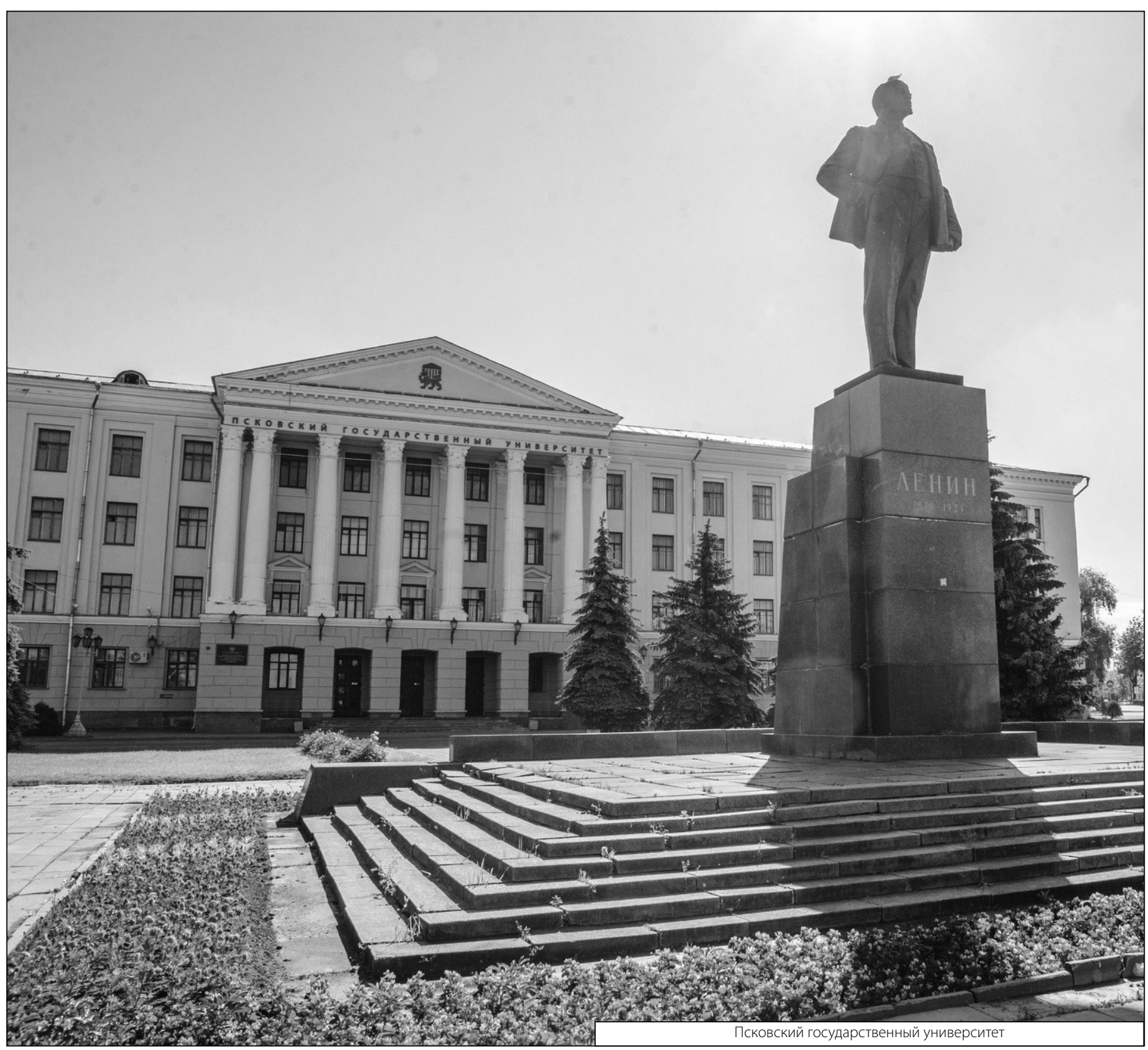

